Boise State University

ScholarWorks

$1-1-2018$

\title{
Academic Libraries as Active Contributors to Student Wellness
}

Elizabeth Ramsey

Boise State University

Mary C. Aagard

Boise State University 


\title{
Academic Libraries as Active Contributors to Student Wellness
}

\author{
Elizabeth Ramsey \\ Associate Professor/Librarian \\ Albertsons Library \\ Boise State University \\ elizabethramsey@boisestate.edu \\ Mary C. Aagard \\ Associate Professor/Head of Access Services \\ Albertsons Library \\ Boise State University \\ maryaagard@boisestate.edu
}

\begin{abstract}
Colleges and universities have come to realize that student wellness is a factor in student retention and success. While academic libraries have not generally been included in wellness initiatives they are strategically placed on college campuses to play an essential role. By parlaying their reputations as trusted information providers and community centers, academic libraries can partner with more traditional campus health providers to be active and effective participants in this essential form of outreach.
\end{abstract}

Keywords: outreach, student wellness, wellbeing, holistic health

\section{Introduction}

While student wellness has traditionally been seen as the purview of health services or campus recreation departments, colleges and universities are increasingly considering the whole life of the student. Many educational institutions, such as Texas Christian, University of Illinois, and University of Mary Washington, center their student wellness programs on some version of Hettler's Six Dimensions of Wellness (2018). As developed by Hettler, the six dimensions of wellness include: occupational, physical, social, intellectual, spiritual, and emotional aspects. However, some universities edit or add to these dimensions according to how they view student wellness. Vanderbilt University expands their "wellness wheel" to include environmental and sexual health dimensions. University of North Carolina at Pembroke has replaced the occupational dimension with an environmental one.

This trend to support student wellbeing holistically is in contrast with the past, where university concerns about student wellness were more likely centered on problem behavior such as suicide, binge drinking, and sexual violence. However, research has found that in supporting student wellness as a whole, universities are contributing to student success, including retention and graduation. LaFountaine, Neisen, and Parsons (2006) suggest that a focus on wellness behaviors impacts college students' academic success as well as assisting in the development of sustainable healthy behaviors for their lifetimes. Mental health particularly has implications for many aspects of wellbeing, including not only academic success, but also drug abuse, future employment, and relationships (Eisenberg et al. 2007). Rayle and Chung (2007) found that social support is also key to reducing academic attrition rates for first-year students. In implementing Hettler's model and others like it, colleges are creating learning opportunities for wellbeing that may impact students for the rest of their lives. Academic libraries can be important contributors to these efforts.

\section{Librarians and Trust}

Although academic libraries are not always present in formal university wellness strategies, they regularly contribute to student wellbeing through their day-to-day interactions within the library and classroom. By reputation, libraries are safe spaces with trusted authorities to help their patrons, providing confidential access to information on potentially sensitive and/or taboo topics. Libraries are also champions of equal access to information, at times battling local norms 
This is an author-produced, peer-reviewed version of this article. The final, definitive version of this document can be found online at College \& Undergraduate Libraries, published by Routledge. Copyright restrictions may apply. doi: 10.1080/10691316.2018.1517433

to ensure that resources are freely available to the entire community. Creative Penn State librarians promoted their resources on sexual health at a Sex on Campus booth at a student health fair to positive student responses (Imler and Tomaszewski 2007).

Stanford University found an innovative way to support their community's sexual wellbeing by installing a vending machine on campus that dispensed the morning-after pill, condoms, and other sexual health products (Caron 2017). Inspired by this article, Boise State student government representatives proposed a similar vending machine to be housed in the library. The students' reasons for placing the machine in the library included timely access and a convenient location: the library was open longer hours compared with campus health services and the library was seen as a neutral location that was physically closer to dormitories and campus housing while providing more comfort and privacy when buying sexual health products. With support from campus health services and the university bookstore, Albertsons Library plans to install the vending machine in a quiet nook of the library in the near future.

College students are often exploring their sexuality as well as other aspects of their developing identities; the broad spectrum of resources in academic libraries can provide confidential, carefully curated resources to aid students in those explorations. Academic librarians are essential players in these information explorations, working to foster better searching and critical thinking skills in their communities by helping to combat a serious deficiency in college students' abilities at finding, evaluating and interpreting health information (Ivanitskaya, O’Boyle, and Casey 2006). Through reference interviews, classroom instruction, and online guides, academic libraries contribute to the intellectual wellness of students. These efforts impact additional dimensions of health in that students who are information literate are better prepared to navigate the information landscape by discovering credible health and wellness resources for their mental, physical, and spiritual wellbeing.

\section{Collaboration is Key}

By partnering with academic libraries, campus institutions that focus on student wellbeing can parlay student trust in libraries and library staff to reach out to a larger, and perhaps more receptive target audience. In turn, libraries enhance their reputations as information centers while contributing to students' quality of life and their abilities to complete their educational goals. The most successful collaborations are built around these mutual goals and involve long-term planning and timely communication. Some libraries even formalize these partnerships by assigning librarians as liaisons to student affairs, health centers and/or recreation centers. "The key is recognizing the specific and unique needs of students, understanding the information component of these needs and seeking out collaborators to assist us in addressing those needs" (Love and Edwards 2009, 24).

Fullerton (2011) asserts that providing wellness opportunities outside the more traditional venues of health and recreation centers can be a more inclusive and far-reaching way to impact student wellness. Dahl (2007) envisions these partnerships to include the library, expanding the traditional liaison role to include non-academic units that support students' perhaps unmet needs. Albertsons Library at Boise State provides an example of a more informal collaboration, establishing a successful, multi-faceted partnership with campus Health Services to facilitate student wellbeing.

Several times each semester Albertsons Library sets aside space near the highly trafficked lobby for nutritionists from Health Services. The nutritionists offer healthy versions of snacks as well as nutrition information. Research at the University of Kentucky indicated improvements in dietary habits from these types of nutrition education programs (McMullen et al. 2017). The library also sets up space for Health Services practitioners during the fall to provide flu shots for the campus community. Additionally, peer educators from Health Services use library space several times during the school year, offering their fellow students tips for stress management as well as information about support services on campus and in the community. In addition to offering space, the library also provides promotions for all of these events through their social media channels, a slide program that runs on all computers in the library, and with "Toilet Talk" flyers that are placed in library restroom stalls.

In yet another important contribution to student wellness on the Boise State campus, library staff are collaborating with the Campus Assessment Resource and Education (CARE) program. Research has shown that not only are mental disorders present on college campus, but their severity has been increasing. To compound the problem, many mental 
This is an author-produced, peer-reviewed version of this article. The final, definitive version of this document can be found online at College \& Undergraduate Libraries, published by Routledge. Copyright restrictions may apply. doi: 10.1080/10691316.2018.1517433

disorders are untreated (Hunt and Eisenberg 2010). Untreated mental disorders can result in distressing, disturbing, and irrational behaviors; the CARE program offers a discreet, confidential method for reporting these behaviors and seeking assistance/treatment.

Unawareness or unfamiliarity with service options are among the reasons college students do not seek treatment. Eisenberg, Golberstein, and Gollust (2007) found that nearly half of the students they surveyed did not understand that their health insurance included mental health visits. Staff at Albertsons Library are informing themselves to be better advocates and promoters of health service options on the Boise State campus. Recently, the library staff received training from counselors at Boise State's Health Services on the CARE program and other options for getting help for themselves and the campus community. In educating themselves, library staff have improved their abilities at recognizing moments for intervention and promoting counseling and other services.

\section{Library as Place}

More and more academic libraries are making strategic upgrades inside their physical space to accommodate the "whole" student. The learning commons is an example of how libraries are rethinking their role on campusprioritizing students' needs to inform programming, collections, and space use. Janicke Hinchliffe and Wong suggest that Hettler's Wellness Wheel can serve libraries well in considering the redevelopment of their spaces to support "student growth and development in a holistic and integrative way" (2010, 221).

Concerns for furniture choices are one aspect of rethinking the library as a learning commons. As workplaces and social spaces for students, libraries have to consider a wide variety of functions for the furniture they provide. Study carrels and quiet spaces are still a mainstay, but libraries are also considering the needs of those who study more socially, preferring to work in groups or surrounded by community. More libraries are including easily movable furniture to allow students to reconfigure spaces as they are needed. Ergonomics are an important consideration in furniture type and placement according to DeClercq and Cranz (2014); stand-up desks and easily adjustable furniture provide for better posture and less stress while working long-term. DeClercq and Cranz also recommend situating furniture in natural light wherever possible, and adding softer, less formal furniture to allow for students who wish to socialize, rest, or study in less upright postures.

Resting in libraries is natural according to Wise (2018), who noted that libraries are ideally situated as places to nap; as teens and young adults are notoriously sleep deprived, offering quiet places with comfortable furniture may be an important way that libraries can support student wellbeing. McGee, Nagel, and Moore (2003) assert that spiritual health is also an important health dimension for college students' wellbeing that should be supported. Some libraries are offering quiet spaces as places for meditation/prayer, helping reduce student stress and anxiety. Recharging often includes food and drink, and, while many of us can remember a time not long ago when food and drink were generally not allowed in libraries, now food and drink is the norm at many academic libraries, functioning, like informal furniture and quiet space, to help students recharge and refuel. Providing opportunities for a "quick break and socializing" is an essential for modern academic libraries according to McMullen $(2008,6)$.

\section{Finals Weeks and Stress Relief}

Libraries have become a central place for promoting self-care during final exams, a stressful time for students. Many of the relationships librarians build with campus wellness units culminate in the last two weeks of the semester. Partnering with other organizations and units, academic libraries provide stress-relieving activities that include free coffee and snacks, yoga breaks, kittens and therapy animal visits, designated resting areas, and arts and crafts. Many libraries extend their operating hours to accommodate late night/early morning studiers. These activities are usually low cost or can be accommodated by current staffing and volunteers.

The success of many of these initiatives provides evidence for academic libraries to consider hosting non-academic services at all times and not just during known high-stress periods like final exams. Andrews and Wilding (2004) found that for college students in the UK, the most common stressor was relationships. They also noted that the financial burdens of a college education are another stressor for students. By reaching out to students through stress relief programming throughout the year, academic libraries may be better addressing these potential health adversities. "Finding stress reduction activities at the library may seem a natural progression for students as they maneuver their academic and social paths on campus,” (Meyers-Martin and Borchard 2015, 523). 
This is an author-produced, peer-reviewed version of this article. The final, definitive version of this document can be found online at College \& Undergraduate Libraries, published by Routledge. Copyright restrictions may apply. doi: 10.1080/10691316.2018.1517433

\section{Conclusion}

Academic librarians are natural connectors, guiding their users to not only resources, but also connecting them to people, services, and spaces that can provide assistance. They can contribute these inherent strengths to support student wellness and overall success through partnerships with a wide array of student services. By asserting their place in this form of caregiving, academic libraries can contribute to the lifelong health, wellbeing, and success of their students.

\section{References}

Andrews, Bernice, and John M. Wilding. 2004. "The Relation of Depression and Anxiety to Life Stress and Achievement in Students.” British Journal of Psychology 95(4): 509-521.

Caron, Christina. 2017. "Students Look to Vending Machines for Better Access to Morning-After Pill.” The New York Times. Sept. 28, 2017. https://www.nytimes.com/2017/09/28/us/plan-b-vending-machine.html

Dahl, C. 2007. "Library Liaison with Non-Academic Units: A New Application for a Traditional Model.” Partnership 2(1). https://doi.org/10.21083/partnership.v2i1.242

DeClercq, Caitlin P., and Galen Cranz. 2014. "Moving Beyond Seating Centered Environments: Opportunities and Challenges Identified in a POE of a Campus Library.” The Journal of Academic Librarianship 40(6): 574584. https://doi.org/10.1016/j.acalib.2014.08.005

Eisenberg, Daniel, Ezra Golberstein, and Sarah E. Gollust. 2007. "Help-Seeking and Access to Mental Health Care in a University Student Population.” Medical Care 45(7): 594-601.

Eisenberg, Daniel, Sarah E. Gollust, Ezra Golberstein, and Jennifer L. Hefner. 2007. "Prevalence and Correlates of Depression, Anxiety, and Suicidality among University Students.” American Journal of Orthopsychiatry 77(4): 534-542.

Fullerton, Darren S. 2011. “A Collaborative Approach to College and University Student Health and Wellness.” New Directions for Higher Education 153: 61-69. https://dx.doi.org/10.1002/he.427

Hettler, Bill. 2018. “The Six Dimensions of Wellness.” National Wellness Institute. https://www.nationalwellness.org/page/Six_Dimensions.

Hunt, Justin, and Daniel Eisenberg. 2010. "Mental Health Problems and Help-Seeking Behavior among College Students.” Journal of Adolescent Health 46(1): 3-10.

Imler, Bonnie, and Michelle Tomaszewski. 2007. “The Powers of Attraction.” American Libraries 38(9): 60-61.

Ivanitskaya, Lana, Irene O’Boyle, and Anne Marie Casey. 2006. "Health Information Literacy and Competencies of Information Age Students: Results from the Interactive Online Research Readiness Self-Assessment (RRSA).” Journal of Medical Internet Research 8(2). https://dx.doi.org/10.2196\%2Fjmir.8.2.e6

Janicke Hinchliffe, Lisa, and Melissa Autumn Wong. 2010. "From Services-Centered to Student-Centered: A "Wellness Wheel” Approach to Developing the Library as an Integrative Learning Commons.” College \& Undergraduate Libraries 17(2-3): 213-224. https://doi.org/10.1080/10691316.2010.490772

LaFountaine, Janna, Mary Neisen, and Rachelle Parsons. 2006. "Wellness Factors in First Year College Students." American Journal of Health Studies 21(3-4): 214-218.

Love, Emily, and Margaret B. Edwards. 2009. "Forging Inroads Between Libraries and Academic, Multicultural and Student Services.” Reference Services Review 37(1): 20-29. https://doi.org/10.1108/00907320910934968

McGee, Melissa, Liza Nagel, and Meighan Moore. 2003. "A Study of University Classroom Strategies Aimed at Increasing Spiritual Health.” College Student Journal 37(4): 583-594.

McMullen, Jennifer, Melinda Ickes, Melody Noland, and Don Helme. 2017. "Evaluation of College CHEF, a Campus-Based, Culinary Nutrition Education Program.” Building Healthy Academic Communities Journal 1(1): 29-41.

McMullen, Susan. 2008. “US Academic Libraries: Today’s Learning Commons Model.” Librarian Publications. 14. https://docs.rwu.edu/librarypub/14

Meyers-Martin, Colleen, and Laurie Borchard. 2015. "The Finals Stretch: Exams Week Library Outreach Surveyed.” Reference Services Review 43(4): 510-532. http://dx.doi.org/10.1108/RSR-03-2015-0019

Rayle, Andrea Dixon, and Kuo-Yi Chung. 2007. "Revisiting First-Year College Students' Mattering: Social Support, Academic Stress, and the Mattering Experience.” Journal of College Student Retention: Research, Theory \& Practice 9(1): 21-37. 
This is an author-produced, peer-reviewed version of this article. The final, definitive version of this document can be found online at College

\& Undergraduate Libraries, published by Routledge. Copyright restrictions may apply. doi: 10.1080/10691316.2018.1517433

Wise, Mary J. 2018. “Naps and Sleep Deprivation: Why Academic Libraries Should Consider Adding Nap Stations to their Services for Students.” New Review of Academic Librarianship 24(2): 192-210. https://doi.org/10.1080/13614533.2018.1431948 